\title{
Rapid Stain Biomarker: A Novel Tool for the Forensic Detection of Saliva (Effect of Time and Surface on its Reliability)
}

\author{
Nesrine Abdel Rahman Mahmoud ${ }^{1}$ and Ali Mohamed Zaki ${ }^{2}$ \\ ${ }^{1}$ Department of Forensic Medicine and Clinical Toxicology. \\ ${ }^{2}$ Department of Microbiology and Immunology. \\ Faculty of Medicine, Ain Shams University, Cairo, Egypt.
}

\begin{abstract}
Saliva is one of the vital fluids secreted by the human body; it can be deposited on the human skin or other materials through biting, sucking, licking and kissing. Saliva stains encountered in forensic casework is an important source of DNA; so, it is considered an important evidence for personnel identification. The rapid Stain Identification of Human Saliva (RSID ${ }^{\mathrm{TM}}$-Saliva) bioassay is designed to detect specifically the presence of human salivary $\propto$-amylase enzyme. Test development is completed within 10 minutes and can detect as little as $1 \mu$ l of human saliva. The detection protocol can be completely integrated into the procedures for DNA extraction and analysis.

Aim: Assess the efficacy of RSID ${ }^{\mathrm{TM}}$-Saliva strip test for the detection of human saliva under some different variables (different surfaces \& different time intervals).Evaluate the quality of DNA extracted from unpreserved saliva and the possibility of its usage as evidence in forensics.

Methodology: Fifty two saliva samples were collected from four volunteers. Forty eight of them were deposited over surfaces of different nature (plastic bottles, glass cup and cigarette butts) at the same time. Four saliva samples were collected directly from the floor of the mouth of each participant by a cotton swab (positive control group). All samples were left to dry for $10 \mathrm{~min}$ at room temperature then extracted and analyzed according to the protocol designed for (RSID ${ }^{\mathrm{TM}}$-Saliva). Collected samples were studied as three tested groups and as control groups. Saliva samples collected from each participant were categorized into four subgroups according to the time interval of saliva extraction [zero (on the spot), 10, 20, and 30 days].Positive samples for saliva identification were subjected to DNA extraction and typing; as three autosomal primers short tandem repeats (STRs) specific to human genomic DNA (D21S11, D18S51 and CSF1PO) were amplified by polymerase chain reaction (PCR); then subjected to separation and analysis of fragments size by agarose gel electrophoresis to determine their allelic size through comparison to the standard allelic 100 bp ladder.

Results: Saliva could be identified in $100 \%$ of tested samples as well as for the positive control samples, which were subjected to successful DNA extraction followed by PCR amplification of the chosen three STRs. Results of agarose gel revealed that the sizes of these PCR products were in accordance with the 100 bp DNA ladder; validating the good quality and quantity of the extracted DNA

Conclusion: the current study demonstrated that non-stored saliva deposited over different surfaces for up to 30 days presents an ideal source for DNA which may be used for forensic identification. The study also evidenced that the new RSID-saliva strip test is a fast, easy, sensitive and reliable method for saliva identification over different surfaces.
\end{abstract}

Key words Saliva, RSID, DNA, PCR.

\section{Introduction}

I dentification and detection of body fluids at a crime scene are very important aspects of forensic science; identified sample undergoes further laboratory testing including DNA analysis. Sometimes just knowing the identity of a fluid can be enough to influence the outcome of a case. This is not always an easy task, since many body fluid stains are either invisible to the naked eye or similar in appearance to other fluids or substances. Even when the identity of a stain may seem obvious to a forensic investigator, absolute confirmation is necessary 
for the evidence to be used in court to either prove or disprove a fact in a case. Physical tests performed on these questioned stains allow crime scene investigators and laboratory technicians to identify a fluid or to confirm its absence. The most common body fluids found at crime scenes are blood, semen, and saliva; they play important roles including the contribution of valuable DNA evidence (Virkler and Lednev, 2009).

Saliva is one of the vital fluids secreted by the human body; it can be deposited on human skin or other materials through biting, sucking, licking and kissing. Detection of saliva stains encountered in forensic casework is one of the important tasks for forensic serologist as saliva is an important source of DNA; so, it is considered an important evidence for personal identification (Saukko and Knight, 2016).

Unfortunately, dried saliva stains are invisible to the human eye, which makes it difficult for recognition and collection. More over saliva DNA -deposited on skin- is difficult to be collected and extracted. Therefore, an improved collection method is required first to identify the invisible saliva stains on human skin and then proceed with other methods of extracting DNA for identification (Anzai-Kanto et al., 2005).

Various detection methods for dried saliva stains have been tried out like use of chemicals, lasers and fluorescence, but each test has its own limitations; as lack of specificity, sensitivity and lack of integration into current DNA-based protocols. As well as these detection methods require significant time and effort (Nanda et al., 2011).

So, the rapid Stain Identification of Human Saliva (RSID ${ }^{\mathrm{TM}}$-Saliva) bioassay is designed to detect specifically the presence of human salivary $\propto$-amylase enzyme. It is fast, easy, and reliable for detection of human saliva; test development is completed within 10 minutes and can detect as little as $1 \mu$ l of human saliva. The detection protocol can be completely integrated into the procedures for DNA extraction and analysis. The test detects saliva stain from envelopes, glass bottles, cans, swabs, plastic lids etc., before they are processed for DNA-STR analysis (McAllister et al., 2016).

\section{Aim of the work}

To assess the efficacy of RSID ${ }^{\mathrm{TM}}$-Saliva strip test for the detection of human saliva under some different variables (different surfaces \& different time intervals).

To determine the applicability of non-preserved human saliva as a presumptive cost saving tool for personal identification.

\section{Materials and Methods \\ $>$ Materials}

(A) Materials used for saliva extraction and identification:

$>$ Lateral flow immunochromatographic biomarker assay; Rapid Stain Identification of Human Saliva Kit (RSID ${ }^{\text {TM}}$-Saliva).Cat No. /ID: 0100. Manufactured by: Independent Forensics. Kit contains:
1) Test cassettes: 25 test cassettes individually wrapped and sealed in moisture-proof foil (a silica gel desiccant pouch has been added).

2) $5 \mathrm{~mL}$ of RSID ${ }^{\mathrm{TM}}$-Saliva Running Buffer.

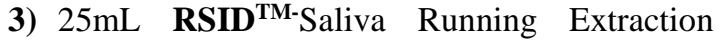
Buffer.

(B) Materials used for DNA extraction and amplification

1) DNA was extracted using Qiagen extraction Kit QIAamp DNA Blood Mini Kit (50) Cat No. /ID: 51104. Kit contains (50 QIAamp Mini Spin Columns, QIAGEN Protease, Reagents, Buffers, $2 \mathrm{ml}$ Collection Tubes).

2) Polymerase chain reaction (PCR) was performed using Qiagen HotStarTaq DNA

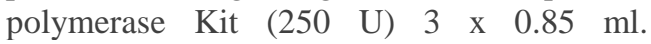
HotStarTaq DNA polymerase. Cat No. /ID: 203203. Kit contains (250 units HotStarTaq DNA Polymerase, $2 \mathrm{ml}$ of PCR Buffer, 2ml of Q-solution and $1.2 \mathrm{ml}$ of

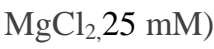

3) Amplification of STR loci: Primers were synthesized by the BIOSEARCH TECHNOLOGIES (LGC), according to the sequences described in the literature. The studied loci and their primer sequences are listed in table (1).

(C) Tested surfaces:

1) Dry plastic bottles.

2) Dry glass cups.

3) Cigarettes butts.

\section{Ethical considerations}

An interview was conducted with each volunteer before participating in the study to clarify the aim of study, and type of the required samples, analyses that will be done on samples donated in addition to scientific benefits to be expected from the application for the community.

All participants were assured about the confidentiality of all data, the findings discovered during examination and preservation of samples. In addition, the right to refuse participation in the study was confirmed for all participants before obtaining the consent for participation in this study. Also, no physical, financial, moral, social nor health hazards would be inflicted on participants in this study. After that, the approval of the Ethical Committee at Faculty of Medicine Ain Shams University (Code number: FWA000017585) was obtained.

\section{$>$ Methods}

The saliva samples were collected from four adult participants -randomly selected- at the same time on the same day.

\section{$\underline{\text { Inclusion criteria }}$}


Samples were collected from the participants in a spontaneous (non-induced) manner. The saliva samples were obtained after at least an hour of brushing teeth and eating or drinking anything. This was to ensure that the samples were collected under near constant conditions, to minimise the variation in amylase concentrations and to remove food residue (McAllister et al., 2016).

\section{$>$ Exclusion criteria}

According to Beltzer et al., (2010) saliva samples in the following conditions were excluded from the study because they compromise the assay method and to avoid DNA contamination and PCR inhibitors.

1) Ingestion of foods with high sugar or acidity, or high caffeine content, alcohol or nicotine consumption immediately before sample collection.

2) Consumption of over-the-counter medications within the prior 12 hours.

3) Vigorous physical activity and the presence of oral diseases or injury.

4) Ingestion of a major meal within 60 minutes of sample collection.

5) Brushing teeth within 45 minutes prior to sample collection.

6) Dental work should not be performed within 24 hours prior to sample.

$>$ Method of sample collection

In order to maintain consistency of collected sample, we use the passive drool technique Beltzer et al., (2010). Whole saliva that pools on the floor of the mouth was left to drop directly on the tops of glass cups, plastic bottles and cigarette butts. Samples were left to dry for $10 \mathrm{~min}$ at room temperature $\left(25 \mathrm{C}^{\circ}-35 \mathrm{C}^{\circ}\right)$; then each group was analyzed for saliva identification, DNA extraction, PCR amplification and agarose gel analysis at its specific time interval $(0$, 10,20 and 30 days from the time of retrieval from the dry surface).

\section{$>$ Grouping}

A total of fifty two saliva samples were collected from four volunteers. Forty eight of them were deposited over surfaces of different nature (plastic bottles, glass cup and cigarette butts) at the same time. Four saliva samples were collected directly from the floor of the mouth of each participant by a cotton swab (positive control group). All samples were left to dry for $10 \mathrm{~min}$ at room temperature then extracted and analyzed according to the protocol designed for The Rapid Stain Identification Test (RSID ${ }^{\mathrm{TM}}$-Saliva). Collected samples were studied as three tested groups and one control group as follows:

\section{- Test groups:}

- Group (I): samples over the tops of dry plastic bottles.

- Group (II): samples over the tops of dry glass cups.

- Group (III): samples over cigarette butts.

In each group, saliva samples collected from each participant were categorized into four subgroups ( $a, b, c$ and d) according to the time interval of saliva extraction [zero (on the spot), 10, 20, and 30 days] respectively.

Positive samples for saliva identification will be subjected to DNA extraction and typing; as three autosomal primers STRs specific to human genomic DNA (D21S11, D18S51 and CSF1PO) were amplified by PCR; then subjected to separation and analysis by agarose gel electrophoresis to determine their allelic size through comparison to the standard allelic $100 \mathrm{bp}$ ladder.

- Control group (IV): was done to ensure the validity of the kit strips and to detect any contamination by a non-human DNA. It was subdivided into:

- Subgroup IV (a) positive control group: the samples were directly subjected to saliva extraction by (RSID ${ }^{\mathrm{TM}}$-Saliva) kit and DNA extraction and amplification by PCR then analyzed by agarose gel electrophoresis as before. This group was designed to detect the efficacy of the (RSID ${ }^{\mathrm{TM}}$-Saliva) kit, to compare DNA extracted directly from saliva swabs at (zero hour) to those extracted from saliva over different surfaces at different time intervals, and to check the purity of extracted DNA which is used as data base for each participant.

- Subgroup IV (b) negative control group: (RSID ${ }^{\mathrm{TM}}$-Saliva) kit's extraction and running buffer-only-were directly subjected to saliva extraction procedure and DNA extraction and amplification by PCR then analyzed by agarose gel electrophoresis as before. This group was designed to detect the efficacy of the (RSID ${ }^{\mathrm{TM}}$-Saliva) kit and to determine that the extraction method was totally according to the standard operating procedure (described by the manufacturers) and there was no external contamination of the tested DNA samples at any stage of the process.

(I) Principles of the method:

$>$ Samples extraction and analysis for saliva identification according to (Independent Forensics, 2016):

* Tested samples: At the specific time for sample extraction and analysis for each group; sterile cotton swabs were moistened with double distilled water ( $\mathrm{ddH} 20)$ and used to 'sponge' the dry tops of glass cups and plastic bottles. Cigarette butts were cut. The swabs and the cut cigarette butts were extracted in $300 \mu \mathrm{L} \quad \mathrm{RSID}^{\mathrm{TM}}$-Saliva extraction buffer for half an hour at room temperature. $20 \mu \mathrm{L}$ of the extract was diluted in $80 \mu \mathrm{L}$ of $\mathrm{RSID}^{\mathrm{TM}}$-Saliva Running Buffer 
for $10 \mathrm{sec} .20 \mu \mathrm{L}$ of this extract was loaded into the sample well of the test cassette. The remaining contents of the tube (including the swab batting) were processed for DNA extraction and STR analysis.

* Positive controls: saliva samples deposited directly on a cotton swab were processed in the same manner.

* Negative controls: $20 \mu \mathrm{L}$ of the extraction buffer was added to $80 \mu \mathrm{L}$ RSID $^{\mathrm{TM}}$-Saliva Running Buffer and the total volume was loaded into the sample well of the test cassette.

\section{Scoring results:}

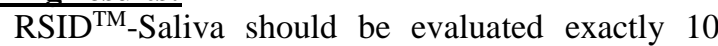
minutes after the addition of sample. (Fig. 1) illustrates expected results:

* A visible red line at the Control (C) position only, indicates a negative result. No alpha-amylase detected but the strip test is working correctly

* Visible red lines at both the Control (C) and Test (T) positions indicate a positive result. Alphaamylase detected.

* A visible red line at the Test (T) position only indicates a failed test. Test failure, no possible conclusion.

$>$ DNA extraction and Amplification : of the following samples:

1) Samples positive for saliva (tested samples over different surfaces) at 10, 20 and 30 days.

2) Samples of saliva collected directly from the floor of the mouth at zero time (positive control group).

3) Buffer containing samples (negative control group) analyzed at zero time.

(II) Procedures:

(A) DNA extraction and purification of saliva samples protocol done according to (Qiagen extraction kit QIAamp ${ }^{\circledR}$ DNA Mini and Blood Mini Handbook, 2016)

- All centrifugation steps are carried out at room temperature $\left(15-25^{\circ} \mathrm{C}\right)$.

- $200 \mu \mathrm{l}$ of saliva yields 3-12 $\mu \mathrm{g}$ of DNA.

- Procedure

1) Pipette $20 \mu \mathrm{l}$ QIAGEN Protease (or proteinase K) into the bottom of a $1.5 \mathrm{ml}$ micro centrifuge tube.

2) Add $200 \mu \mathrm{l}$ from the already prepared RSID ${ }^{\mathrm{TM}}$ Saliva extraction buffer sample to the micro centrifuge tube.

3) Add $200 \mu \mathrm{l}$ Buffer AL to the sample. Mix by pulse-vortexing for $15 \mathrm{~s}$. till a homogeneous solution is formed.

3) Incubate at $56^{\circ} \mathrm{C}$ for $10 \mathrm{~min}$.

4) Add $200 \mu \mathrm{l}$ ethanol (96-100\%) to the sample, and mix again by pulse-vortexing for $15 \mathrm{~s}$. Apply the mixture to the QIAamp Mini spin column. Close the cap, and centrifuge at $6000 \mathrm{rpm}$ for $1 \mathrm{~min}$. Place the QIAamp Mini spin column in a clean $2 \mathrm{ml}$ collection tube and discard the tube containing the filtrate.

5) Repeat the previous step and add $500 \mu$ Buffer AW1, followed by addition of $500 \mu \mathrm{l}$ Buffer AW2 and then add $200 \mu$ Buffer AE. Incubate at room temperature $\quad\left(15-25^{\circ} \mathrm{C}\right)$ for $1 \mathrm{~min}$, and then centrifuge at $6000 \mathrm{rpm}$ for $1 \mathrm{~min}$.

(B) PCR and amplification of STR loci was performed using Qiagen HotStarTaq polymerase Kit according to (The protocol of HotStarTaq ${ }^{\circledR}$ PCR Handbook, 2010)

- The STR loci are polymorphic markers consisting of a variable number of tandem repeats ranging from two to six nucleotides, which are easily amplified by the PCR. They offer a number of advantages, including the ability to obtain results from the degraded samples and extremely small amounts of DNA. Then, in the current study the extracted salivary DNA was used as a template for amplification using three autosomal human specific genes (D21S11, D18S51 and CSF1PO) with relatively small size (ranging from 214 to $323 \mathrm{bp}$ ). These three loci were chosen as they are among the thirteen STR markers selected to form the core of FBI Laboratory's Combined DNA Index System (Fraige et al., 2013).

Important points before starting

-All reaction mixtures were done in an area separate from that used for DNA preparation or PCR product analysis.

\section{Procedure}

- Thaw 10x PCR Buffer, dNTP mix, primer solutions, and $25 \mathrm{mM} \mathrm{MgCl2}$. Solutions were mixed completely before use to avoid localized concentrations of salts.

- Prepare a reaction mix which typically contains all the components needed for PCR except the template DNA. Prepare a volume of master mix $10 \%$. A negative control (without template DNA) should always be included to detect any contamination.

- Mix gently the reaction mix thoroughly and dispense appropriate volumes into PCR tubes.

- Add template DNA ( $<1 \mu \mathrm{g} / 100 \mu \mathrm{l}$ reaction) to the individual tubes containing the reaction mix.

- Place the PCR tubes in the thermal cycler and start the cycling program (number of cycles: 25 35 ) as follows:

- Initial activation step: $15 \mathrm{~min}$ at $95^{\circ} \mathrm{C}$ HotStarTaq DNA polymerase is activated by this heating step.

- 3-step cycling

- Denaturation: $0.5-1 \mathrm{~min}$ at $94^{\circ} \mathrm{C}$

- Annealing: $0.5-1 \mathrm{~min}$ at $50-68^{\circ} \mathrm{C}$. 
- Extension: $1 \mathrm{~min}$ at $72^{\circ} \mathrm{C} \mathrm{e}$

- Final extension: $10 \mathrm{~min}$ at $72^{\circ} \mathrm{C}$

- Specific temperatures and cycling times for specific selected primer pair are shown in (table 2).

- After amplification, samples were stored at 2$8^{\circ} \mathrm{C}$.

(C) Gel Electrophoresis detection:

PCR products $(10 \mu \mathrm{L}$ from each amplified sample) were analyzed using horizontal electrophoresis in $2 \%$ agarose gel stained with ethidium bromide at 100 $\mathrm{V}$ current for 1 hour. After electrophoresis, the agarose gel was photographed to record the presence of amplified products of anticipated sizes. The molecular weight of the PCR products (DNA fragments) was determined by comparison to a 100 bp molecular weight marker (Carvalho et al., 2010).

\section{Results}

(I) Results of saliva extracted from different surfaces (glass, plastic and cigarette butts) and identified by RSID $^{T M}$-Saliva method at different time intervals were as follows:

- The forty eight samples (100\% of tested samples) collected from the four participants over the three different surfaces and at different time interval give positive results (saliva alphaamylase detected) when identified by the (RSID ${ }^{\mathrm{TM}}$-Saliva) kit. This can be easily determined by visual inspection of red lines at both the control (C) and test (T) positions of the strip, which indicate a positive result (table $\mathbf{3}$ and figure 3 ).

- The negative control samples (extraction and buffer solutions) of the (RSID ${ }^{\mathrm{TM}}$-Saliva) gives a visible red line at the control (C) position only that indicates a negative result (absence of saliva alpha-amylase) (table 3 and figures 2 and 3 ).

- The positive control samples; saliva collected on a cotton swab directly from the floor of the mouth -from the four participants- gives visible red lines at both the control (C) and test (T) positions that indicate a positive result (saliva alpha-amylase detected) (table $\mathbf{3}$ and figures $\mathbf{2}$ and 3 ).

(II) (Results of positive saliva samples subjected to DNA extraction, amplification by PCR and analysis by gel electrophoresis for the three studied STR loci (D21S11, CSF1PO and D18S5).

- Quantity of extracted DNA was sufficient for PCR amplification and typing; this was determined by successful extraction of DNA from $100 \%$ of the tested saliva samples deposited on all the tested surfaces at all tested time intervals as well as for the positive control samples (table 5). The negative control sample shows the absence of genomic DNA for extraction. So, it wasn't possible to separate the alleles of these loci; thus no fluorescence emitted at the agarose gel. It was analysed to exclude any external contamination by nucleic acid or protein (table 5 , figures 4,5 and 6 ).

- Three autosomal STR loci of human genomic DNA (D21S11, CSF1PO and D18S5) were amplified by PCR after adjusting the appropriate amplification conditions (as stated in the methodology), then analyzed by agarose gel electrophoresis stained with ethedium bromide at its specific time intervals. Their results were as follows:

Despite the small number of amplified tested loci (D21S11, CSF1PO and D18S5) it was possible to separate the alleles of these loci in the extracted DNA samples collected from different tested surfaces for all tested time intervals as well as from the positive control samples. The comparison of the $100 \mathrm{bp}$ DNA ladder with the produced amplicons' bands indicated that the sizes of these PCR products were in accordance with the expected values. This could be seen as fluorescence emitted when the agarose gel was illuminated by the ultra violet light (table 5, figures 4, 5 and 6 )

Table (1): Characteristics of the three chosen STRs primers (Fraige et al., 2013)

\begin{tabular}{|c|c|c|c|}
\hline Locus & Primer sequence & Repeat sequence & $\begin{array}{l}\text { Allele size } \\
\text { range }(\mathrm{bp})\end{array}$ \\
\hline D21S11 & $\begin{array}{l}\text { A:ATATGTGAGTCAATTCCCCAAG } \\
\text { B:TGTATTAGTCAATGTTCTCCAG }\end{array}$ & $\begin{array}{l}\text { (TCTA)n(TCTG)n [(TCTA)3TA(TCTA)3 } \\
\text { TCA(TCTA)2TCCATA] (TCTA)n-complex }\end{array}$ & $214-240$ \\
\hline D18S51 & $\begin{array}{l}\text { A:CAAACCCGACTACCAGCAAC } \\
\text { B:GAGCCATGTTCATGCCACTG }\end{array}$ & (AGAA)n & $247-318$ \\
\hline CSF1PO & $\begin{array}{l}\text { A:AACCTGAGTCTGCCAAGGACTAGC } \\
\text { B:TTCCACACACCACTGGCCATCTTC }\end{array}$ & (AGAT)n & $299-323$ \\
\hline
\end{tabular}

A: forward primer, B: reverse primer, bp: base pair 
Table (2): PCR conditions for amplification (melting and annealing temperatures) used for the three chosen STRs primers (D21S11, D18S51 and CSF1PO: (BIOSEARCH TECHNOLOGIES (LGC))

\begin{tabular}{|l|l|l|l|}
\hline Primer & Temperature $\left.^{(}{ }^{\circ}\right)$ & Mean temperature $\left.^{\circ}{ }^{\circ}\right)$ & Annealing temperature $\left.^{(} c^{\circ}\right)$ \\
\hline D21S11 A & $\mathbf{5 2 . 0}$ & 49.0 & 53.2 \\
D21S11 B & 46.0 & & \\
\hline D18S51 A & 54.3 & 55.2 & 58.1 \\
D18S51 B & 56.0 & 61.3 & 55.5 \\
\hline CSF1PO A & 58.9 & & \\
CSF1PO B & 63.7 & & \\
\hline
\end{tabular}

A: forward primer, B: reverse primer

Table (3): Shows results of saliva identification extracted from different surfaces (glass, plastic and cigarette butts) versus the control groups; analysed by RSID $^{\mathrm{TM}}$-Saliva method at different time intervals $(0,10,20$ and 30 days). Number of participants $=4$.

\begin{tabular}{|c|c|c|c|c|c|c|c|c|c|c|c|c|}
\hline$c$ & \multicolumn{4}{|c|}{ Glass surfaces } & \multicolumn{4}{|c|}{ Plastic bottles } & \multicolumn{4}{|c|}{ Cigarette butts } \\
\hline Time intervals & $\begin{array}{c}0 \\
\text { day }\end{array}$ & $\begin{array}{c}10 \\
\text { days }\end{array}$ & $\begin{array}{c}20 \\
\text { days }\end{array}$ & $\begin{array}{c}30 \\
\text { days }\end{array}$ & $\begin{array}{c}0 \\
\text { day }\end{array}$ & $\begin{array}{c}10 \\
\text { days }\end{array}$ & $\begin{array}{c}20 \\
\text { days }\end{array}$ & $\begin{array}{c}30 \\
\text { days }\end{array}$ & $\begin{array}{c}0 \\
\text { day }\end{array}$ & $\begin{array}{c}10 \\
\text { days }\end{array}$ & $\begin{array}{c}20 \\
\text { days }\end{array}$ & $\begin{array}{c}30 \\
\text { days }\end{array}$ \\
\hline Participant (1) & $+\mathrm{ve}$ & $+\mathrm{ve}$ & $+\mathrm{ve}$ & $+\mathrm{ve}$ & + ve & + ve & $+\mathrm{ve}$ & $+\mathrm{ve}$ & $+\mathrm{ve}$ & $+\mathrm{ve}$ & $+\mathrm{ve}$ & $+\mathrm{ve}$ \\
\hline Participant (2) & $+\mathrm{ve}$ & $+\mathrm{ve}$ & $+\mathrm{ve}$ & $+\mathrm{ve}$ & $+\mathrm{ve}$ & $+\mathrm{ve}$ & $+\mathrm{ve}$ & $+\mathrm{ve}$ & $+\mathrm{ve}$ & $+\mathrm{ve}$ & $+\mathrm{ve}$ & $+\mathrm{ve}$ \\
\hline Participant (3) & $+\mathrm{ve}$ & $+\mathrm{ve}$ & $+\mathrm{ve}$ & $+\mathrm{ve}$ & $+\mathrm{ve}$ & $+\mathrm{ve}$ & $+\mathrm{ve}$ & $+\mathrm{ve}$ & $+\mathrm{ve}$ & $+\mathrm{ve}$ & $+\mathrm{ve}$ & $+\mathrm{ve}$ \\
\hline Participant (4) & $+\mathrm{ve}$ & $+\mathrm{ve}$ & + ve & $+\mathrm{ve}$ & $+\mathrm{ve}$ & + ve & $+\mathrm{ve}$ & $+\mathrm{ve}$ & $+\mathrm{ve}$ & $+\mathrm{ve}$ & $+\mathrm{ve}$ & $+\mathrm{ve}$ \\
\hline $\begin{array}{c}\text { Buccal swabs } \\
\text { (positive control) }\end{array}$ & & & & & & for $a$ & artici] & & & & & \\
\hline $\begin{array}{c}\text { Extraction and } \\
\text { buffer solutions } \\
\text { (negative control) }\end{array}$ & & & & & & & & & & & & \\
\hline
\end{tabular}

$+v e=$ saliva was identified, $-v e=$ saliva can't be identified

Table (4): Shows percentage of DNA extraction from positive saliva samples over different surfaces (glass, plastic and cigarette butts) as well as for positive and negative control groups collected at different time intervals (10, 20 and 30 days) from four participants.

\begin{tabular}{|c|c|c|c|c|c|c|c|c|c|c|c|}
\hline \multirow{2}{*}{$\begin{array}{c}\text { Tested } \\
\text { surfaces } \\
\\
\text { Time } \\
\text { intervals }\end{array}$} & \multicolumn{3}{|c|}{$\begin{array}{l}\text { DNA extracted from } \\
\text { saliva samples } \\
\text { over glass }\end{array}$} & \multicolumn{3}{|c|}{$\begin{array}{c}\text { DNA extracted from } \\
\text { saliva samples over } \\
\text { plastic }\end{array}$} & \multicolumn{3}{|c|}{$\begin{array}{l}\text { DNA extracted from } \\
\text { saliva samples over } \\
\text { cigarette butts }\end{array}$} & \multirow{2}{*}{$\begin{array}{c}\text { DNA } \\
\text { extracted } \\
\text { from } \\
\text { buccal } \\
\text { swabs }\end{array}$} & \multirow{2}{*}{$\begin{array}{c}\text { DNA } \\
\text { extracted } \\
\text { from samples } \\
\text { of extraction } \\
\text { and buffer } \\
\text { solutions } \\
\end{array}$} \\
\hline & $\begin{array}{c}10 \\
\text { days }\end{array}$ & $\begin{array}{c}20 \\
\text { days }\end{array}$ & $\begin{array}{c}30 \\
\text { days }\end{array}$ & $\begin{array}{c}10 \\
\text { days }\end{array}$ & $\begin{array}{c}20 \\
\text { days }\end{array}$ & $\begin{array}{c}30 \\
\text { days }\end{array}$ & $\begin{array}{c}10 \\
\text { days }\end{array}$ & $\begin{array}{c}20 \\
\text { days }\end{array}$ & $\begin{array}{c}30 \\
\text { days }\end{array}$ & & \\
\hline $\begin{array}{c}\text { DNA } \\
\text { extraction }\end{array}$ & $\begin{array}{c}100 \\
\%\end{array}$ & $\begin{array}{c}100 \\
\%\end{array}$ & $100 \%$ & $\begin{array}{c}100 \\
\%\end{array}$ & $\begin{array}{c}100 \\
\%\end{array}$ & $100 \%$ & $\begin{array}{c}100 \\
\%\end{array}$ & $\begin{array}{c}100 \\
\%\end{array}$ & $\begin{array}{c}100 \\
\%\end{array}$ & $100 \%$ & $0 \%$ \\
\hline $\begin{array}{l}\text { DNA not } \\
\text { extracted }\end{array}$ & 0\% & $0 \%$ & $0 \%$ & $0 \%$ & 0\% & $0 \%$ & $0 \%$ & $0 \%$ & $0 \%$ & $0 \%$ & $100 \%$ \\
\hline
\end{tabular}


Table (5): Shows results of PCR amplification of some saliva samples extracted from different surfaces (glass, plastic and cigarette butts) at different time intervals (10, 20 and 30 days), analyzed by agarose gel electrophoresis and stained with ethidium bromide for the three studied STR loci (D21S11, CSF1PO and D18S5). Number of participants $=4$.

\begin{tabular}{|c|c|c|c|c|c|c|c|c|c|}
\hline Examined Loci & \multicolumn{3}{|c|}{ D21S11 locus } & \multicolumn{3}{|c|}{ CSF1PO locus } & \multicolumn{3}{|c|}{ D18S5 1ocus } \\
\hline Time intervals & $\begin{array}{c}10 \\
\text { days }\end{array}$ & $\begin{array}{c}20 \\
\text { days }\end{array}$ & $\begin{array}{c}30 \\
\text { days }\end{array}$ & $\begin{array}{c}10 \\
\text { days }\end{array}$ & $\begin{array}{c}20 \\
\text { days }\end{array}$ & $\begin{array}{c}30 \\
\text { days }\end{array}$ & $\begin{array}{c}10 \\
\text { days }\end{array}$ & $\begin{array}{c}20 \\
\text { days }\end{array}$ & $\begin{array}{c}30 \\
\text { days }\end{array}$ \\
\hline $\begin{array}{l}\text { Participant (1) } \\
\text { (Saliva over glass) }\end{array}$ & $+\mathrm{ve}$ & $+\mathrm{ve}$ & $+\mathrm{ve}$ & $+\mathrm{ve}$ & $+\mathrm{ve}$ & $+\mathrm{ve}$ & $+\mathrm{ve}$ & $+\mathrm{ve}$ & + ve \\
\hline $\begin{array}{l}\text { Participant (2) } \\
\text { (Saliva over plastic bottle) }\end{array}$ & $+\mathrm{ve}$ & $+\mathrm{ve}$ & $+\mathrm{ve}$ & $+\mathrm{ve}$ & $+\mathrm{ve}$ & $+\mathrm{ve}$ & $+\mathrm{ve}$ & $+\mathrm{ve}$ & $+\mathrm{ve}$ \\
\hline $\begin{array}{l}\text { Participant (3) } \\
\text { (Saliva over cigarette butts) }\end{array}$ & $+\mathrm{ve}$ & $+\mathrm{ve}$ & $+\mathrm{ve}$ & $+\mathrm{ve}$ & $+\mathrm{ve}$ & $+\mathrm{ve}$ & $+\mathrm{ve}$ & $+\mathrm{ve}$ & $+\mathrm{ve}$ \\
\hline $\begin{array}{l}\text { Participant }(4) \\
\text { (Saliva over glass) }\end{array}$ & $+\mathrm{ve}$ & $+\mathrm{ve}$ & $+\mathrm{ve}$ & $+\mathrm{ve}$ & $+\mathrm{ve}$ & $+\mathrm{ve}$ & $+\mathrm{ve}$ & $+\mathrm{ve}$ & $+\mathrm{ve}$ \\
\hline Buccal swab (positive control) & & $+\mathrm{ve}$ & three & coulc & e ides & $\overline{\mathrm{d} \mathrm{fo}}$ & the $s$ & ples) & \\
\hline $\begin{array}{l}\text { Extraction and buffer solutions } \\
\text { (negative control) }\end{array}$ & & & & & $-\mathrm{ve}$ & & & & \\
\hline
\end{tabular}

$+v e=$ Locus identified, $-v e=$ Locus wasn't identified

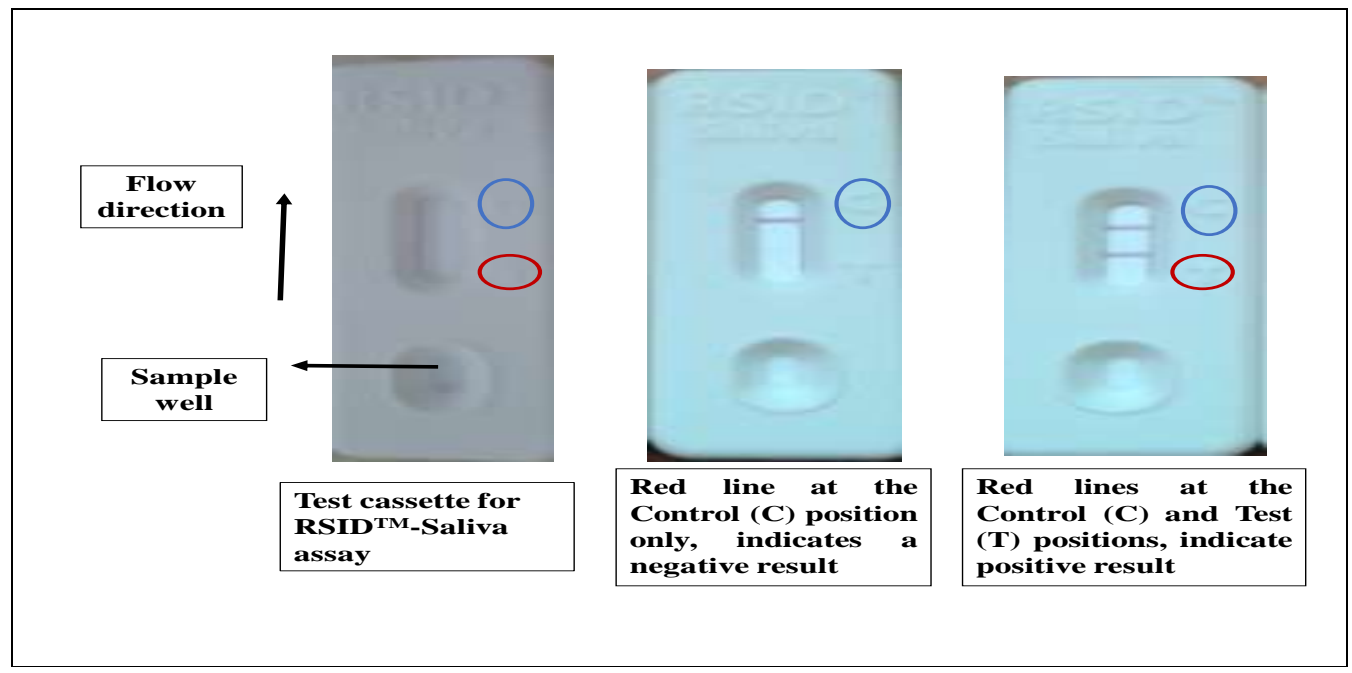

Fig (1): Illustrates expected results in test cassette for RSID $^{\mathrm{TM}}$-Saliva assay

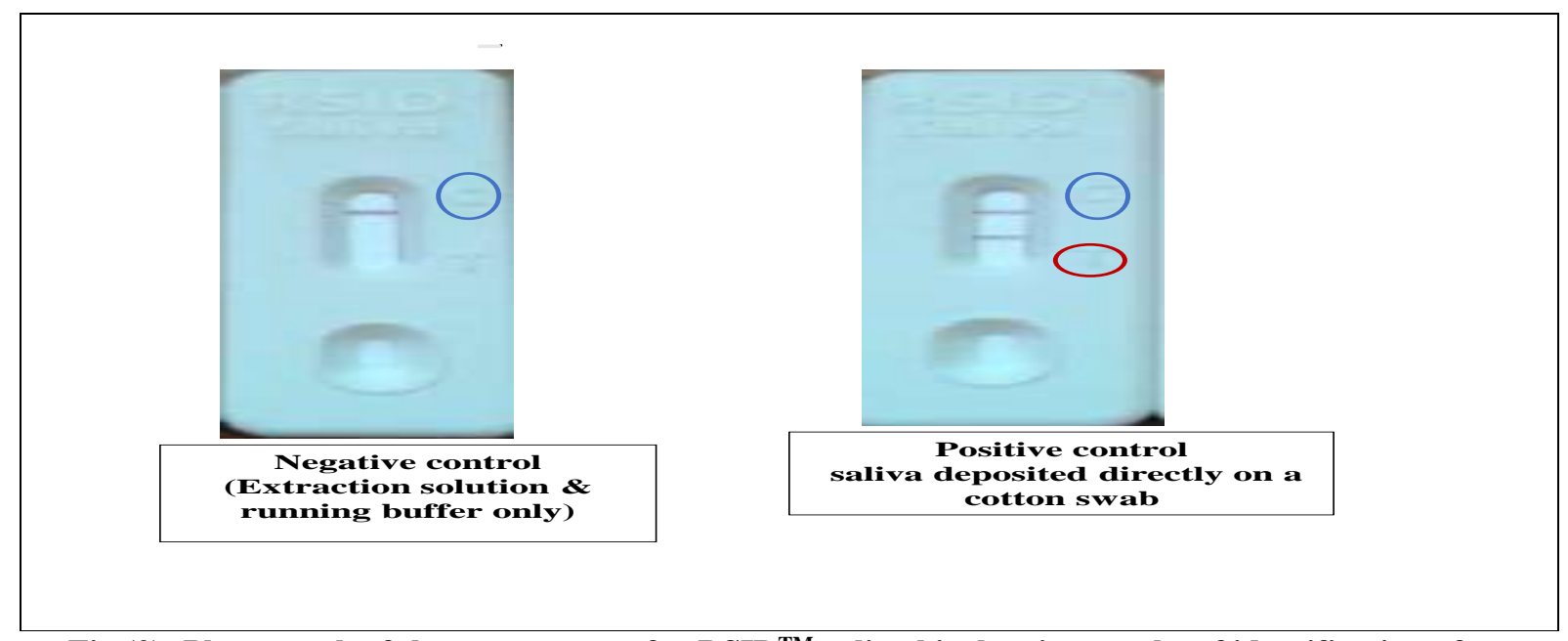

Fig (2): Photograph of the test cassettes for RSID ${ }^{\mathrm{TM}}$-saliva kit showing results of identification of saliva samples of the control groups 


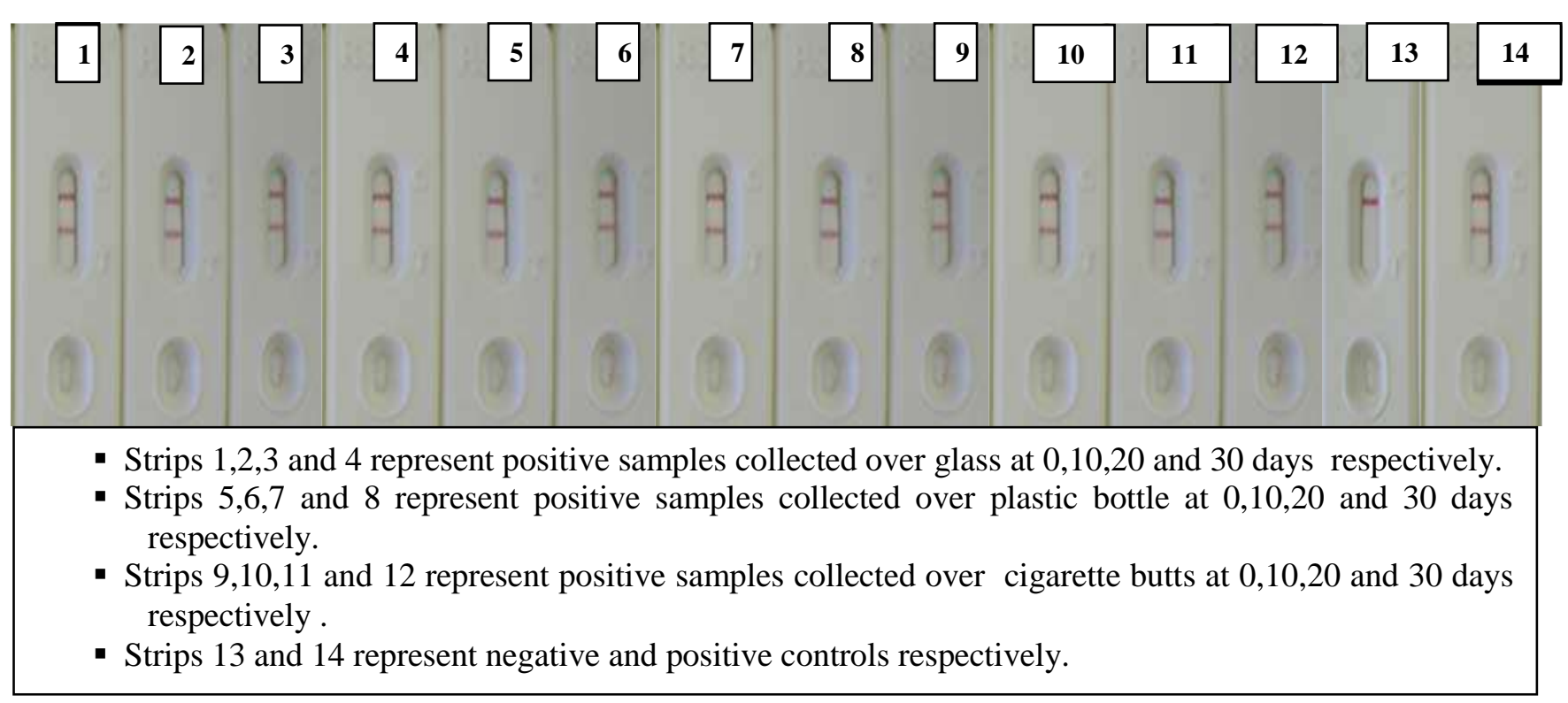

Fig (3): Photograph of the test cassettes for RSID $^{\mathrm{TM}}$-saliva kit showing results of identification of saliva samples collected and extracted from different surfaces at different time intervals

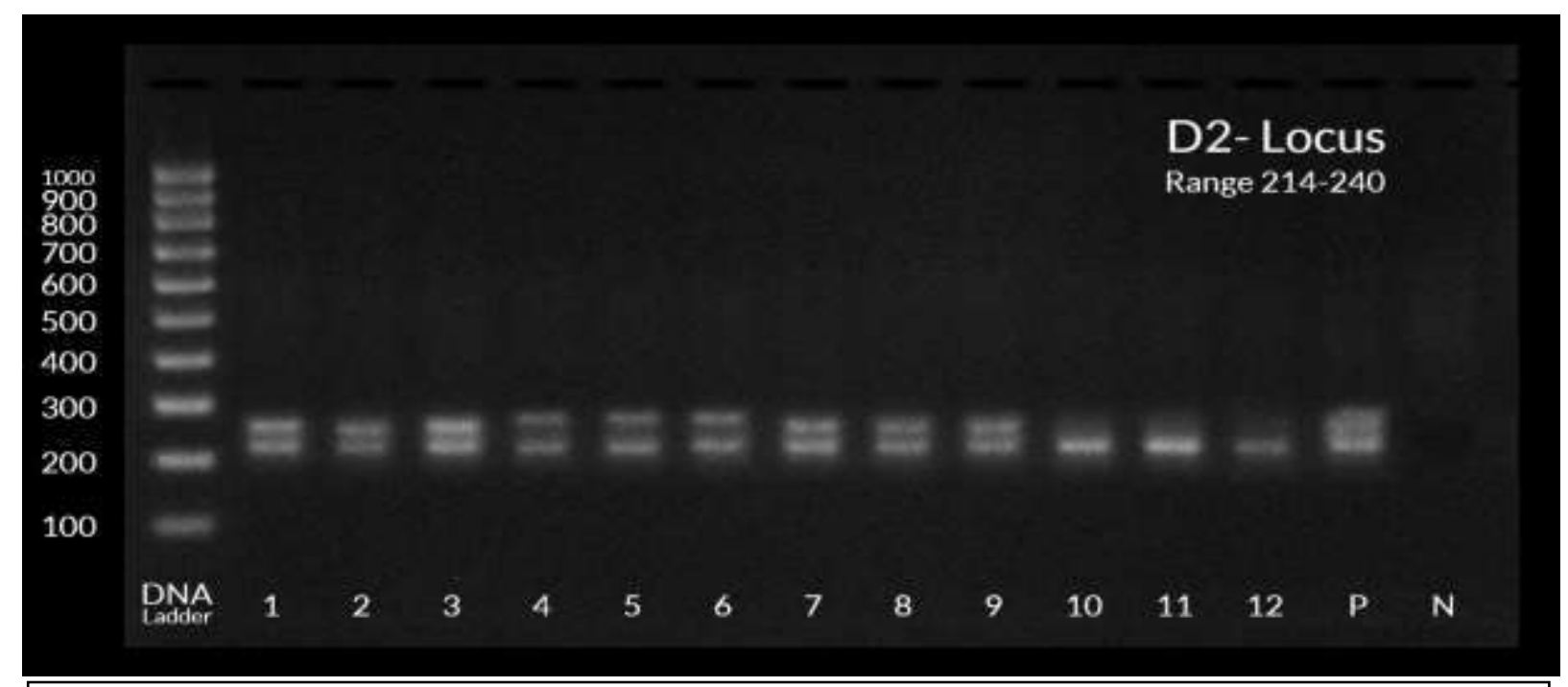

Lane $(\mathrm{P})$ : positive control known saliva on a cotton

Lane (N): negative control RSID ${ }^{\mathrm{TM}}$-Saliva Running Buffer only.

Lanes (1,2 and 3): participant (1) samples collected over glass after 10, 20, and 30 days respectively.

Lanes (4, 5 and 6): Participant (2) samples collected over plastic bottle after 10, 20, and 30 days respectively.

Lanes (7, 8 and 9): Participant (3) samples collected over cigarette butts after 10, 20, and 30 days respectively

Lanes (10,11 and 12): Participant (4) samples collected over glass after 10, 20, and 30 days respectively.

Fig (4): Photograph of DNA patterns obtained from saliva samples extracted from different surfaces (glass, plastic and cigarette butts) as well as positive and negative control groups at different time intervals (10, 20 and 30 days) and subjected to amplification by PCR and analyzed by agarose gel electrophoresis for the studied STR (D21S11- locus). 


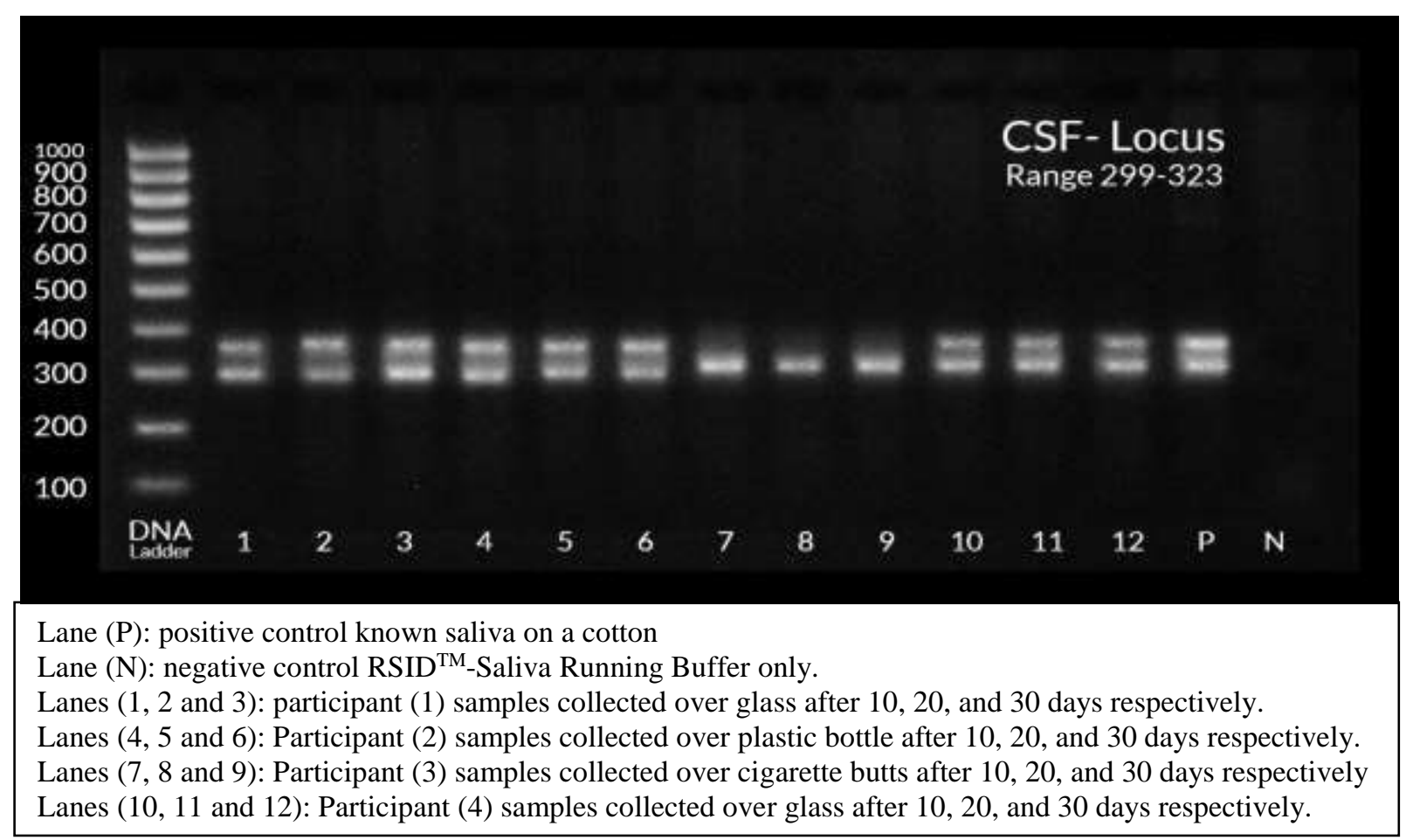

Fig (5): Photograph of DNA patterns obtained from saliva samples extracted from different surfaces (glass, plastic and cigarette butts) as well as positive and negative control groups at different time intervals (10, 20 and 30 days) and subjected to amplification by PCR and analyzed by agarose gel electrophoresis for the studied STR (CSF1PO- locus).

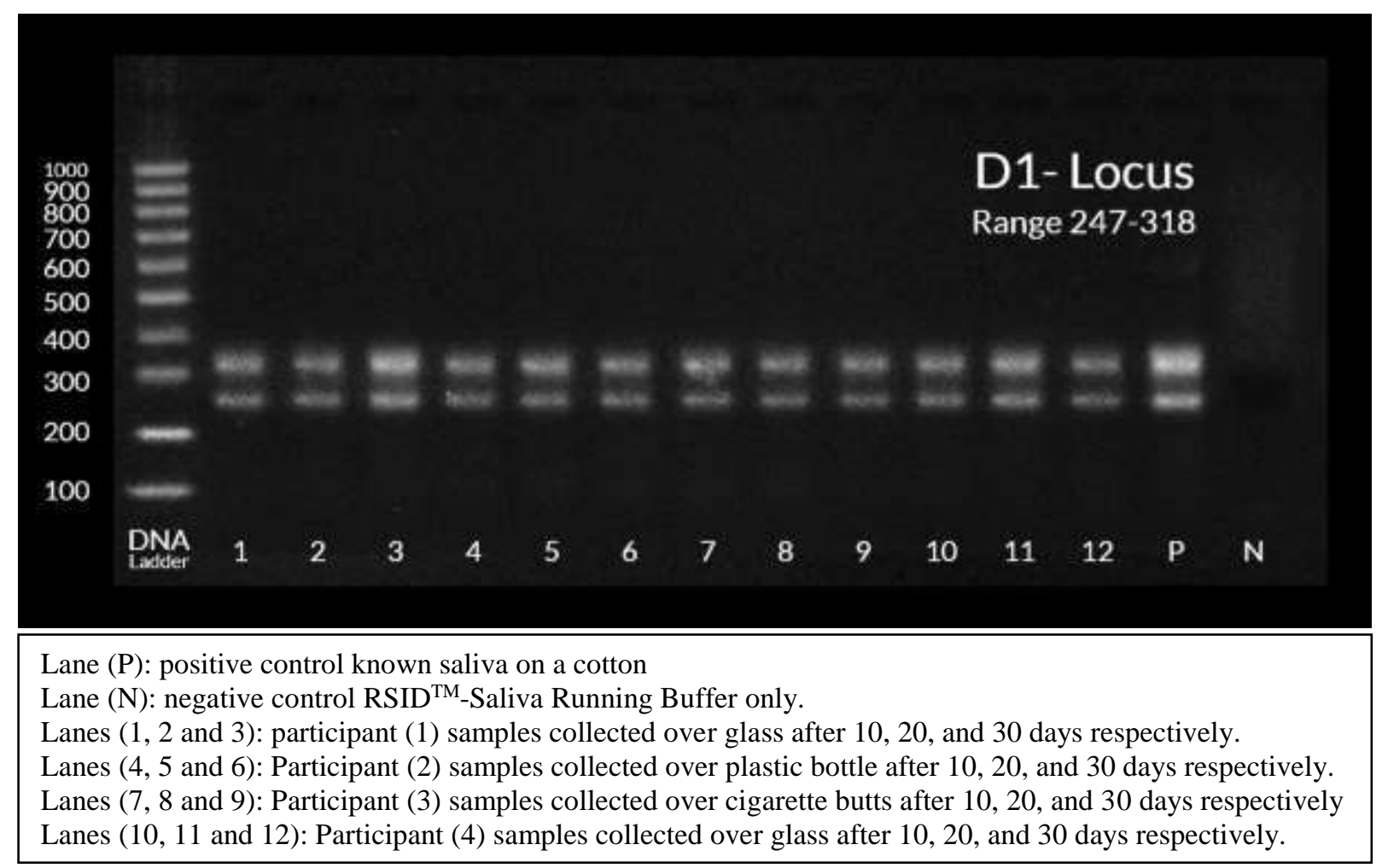

Fig (6): Photomicrograph of DNA patterns obtained from saliva samples extracted from different surfaces (glass, plastic and cigarette butts) at different time intervals (10, 20 and 30 days) and subjected to amplification by PCR and analyzed by agarose gel electrophoresis for the studied STR (D18S51- locus). 


\section{Discussion}

In forensic or police case work the identification of biological stains-blood, saliva, and semen- is a daily task. Not only to know the origin of the body fluid that is important for the correct handling of the evidence in the laboratory, but also to (a) reconstruct what may have occurred during the crime and/or (b) to determine which items of evidence should be further processed for DNASTR testing and identification (Old et al,. 2010).

Saliva stains may be found in about $70 \%$ of crime scenes. It can be deposited on peripheral items that might be important evidence. Generally it is a suitable biological source for DNA profile, as when compared to blood has the following advantages: it is easier, less expensive, requires no specialized personnel for collection, allows for remote collection by the patient, it is painless, well accepted by participants, has decreased risks of disease transmission, does not clot, can be frozen before DNA extraction, has a longer storage time and yields to large amounts of high quality DNA (Goode et al., 2014).

As saliva is a watery fluid; its dry stains are invisible that makes it difficult in collection and identification. Saliva can be probably identified and typed by many amylase assays. These forensic methods for human saliva detection have many drawbacks as lack of specificity, lack of sensitivity, difficult protocols or it can consume big amount of the biological sample (Sinelnikov et al,. 2013). So, a simpler, more specific, and more integrated method was developed by Independent Forensics (Lombard, IL, USA); The Rapid Stain Identification of Human Saliva (RSID ${ }^{\mathrm{TM}}-$ Saliva) Kit which was validated for forensic samples in 2009. It is an immunochromatographic lateral flow assay strip test directed against a specific antigen found in high quantity in human saliva; $\propto$ - amylase enzyme. It is a qualitative test that can detect as little as $1 \mu$ l of saliva and results are recorded as either positive or negative based on the presence or absence of a visible single red or blue line at the "Test" position on the strip 10 min following addition of saliva to the sample well. The results are determined by visual inspection of the strip test and no image analysis or optical reader is required for scoring the test. There is no doubt regarding the results of the analysis; either the test band is visible or it is not. This detection protocol can be completely integrated into forensic laboratory procedures for DNA extraction, amplification before they are processed for DNA-STR analysis (Independent Forensics, 2016).

For the previous considerations, this research work was designed to simulate what real happen in crime scene. Saliva samples collected from volunteers by the passive drool technique, were deposited directly over the tops of glass cups, plastic bottles and cigarette butts and left to dry and to age at room temperature, then each sample was subjected to saliva extraction and identification by (RSID ${ }^{\mathrm{TM}}$-Saliva). Positive samples were subjected to DNA extraction and three STRs of human genomic DNA (D21S11, CSF1PO and D18S5) were amplified by PCR ,then analyzed by gel electrophoresis at its specific time interval (0, 10, 20 and 30 days). Results showed that saliva could be identified in all the tested samples as well as the positive control samples only.

The results of the current study are in consistent with (Old et al., 2010 and Ricci et al., 2014). who stated that in humans, two main isozymes of $\alpha$-amylase exist, salivary and pancreatic; old methods for saliva identification cannot distinguish between these different $\alpha$-amylase isozymes. Thus, the $\mathrm{RSID}^{\mathrm{TM}}$-Saliva kit was developed; it utilises two antihuman-salivary amylase monoclonal antibodies to detect the presence of $\alpha$ amylase rather than its activity which, could be compromised in aged or degraded forensic samples. It is sensitive, accurate, reproducible, easy to use, highly specific for human saliva, stable and non-detrimental analysis as the remaining extract can then be submitted for DNA analysis.

Many studies reported the RSID ${ }^{\text {TM }}$-Saliva kit is more sensitive when compared to previously used immunochromatographic identification methods; SALIgAE® and Phadebas ${ }^{\circledR}$ tests (Pang and Cheung, 2008; Casey and Price, 2010).

McAllister et al, (2016) recorded better extraction and improvement of the visualisation of saliva deposited on non-porous substrates after usage of enhancement techniques (Cyanoacrylate/BY40, Ironoxide PS and Ninhydrin) prior to extraction by RSID kit. These techniques provide a target area for swabbing for subsequent confirmation and DNA tests.

Sinelnikov et al, (2013) reported that numerous experiments using RSID $^{\text {TM}}$-Saliva kit demonstrating the ability of the test to detect dried human saliva stains from a variety of objects that are typically encountered in forensic laboratory case work; as cups, glass, metal, fabrics, plastic, etc. The previous study recommended also the usage of a handheld reader capable of recording and scoring the tests to resolve the ambiguous (i.e. very faint bands) results or when the test was performed by a less experienced personnel.

Trepat and Castelló (2015) evaluated the effects of many factors: age of the dry saliva stain (up to 40 days), environmental condition (at room temperature exposed to sun light) and the type of material (glass, plastic and wood) on the sensitivity of RSID ${ }^{\mathrm{TM}}$ Saliva kit. The results confirmed kit resistance to all the tested influences.

Holtkötter et al, (2018) demonstrated that saliva samples alone or in mixtures containing saliva, semen, blood, menstrual fluid, and urine left at room temperature; then extracted after 7, 14, and 21 days gave positive bands.

Park et al, (2015) study negates the crossreactivity of whole blood; as all the tested blood samples produced negative results. It also demonstrated that this 
kit was the most suitable, sensitive technique for the detection of very low concentration of saliva in expectorated blood found on crime scene; when compared to SALIgAE®, Phadebas ${ }^{\circledR}$ and starch gel diffusion methods. The presence of blood didn't inhibit the kit activity.

As opposed to the previous researches which supported the specificity of the kit; others demonstrated that although this kit is highly specific to human saliva and denoted a negative reaction for many different types of animal saliva and many body fluids as semen, vaginal secretion, blood and urine. However, it gave positive reactions for gorilla and rat saliva, breast milk samples and citrus fruits as lemon, orange, grape fruit etc. (Ricci et al., 2014).

The current study showed that all saliva samplesdeposited on all the tested surfaces at all tested time intervals-as well as the positive control samples; subjected to DNA extraction give DNA quantity sufficient for successful PCR amplification and typing. It was possible to separate the alleles of the tested loci (D21S11, CSF1PO and D18S5); denoting that neither the identification method ( RSID $^{\text {TM}}$-Saliva kit) nor the DNA extraction method interfered with or inhibit DNA amplification. The comparison of the $100 \mathrm{bp}$ DNA ladder with the produced amplicons' bands indicated that the sizes of these PCR products were in accordance with the expected values.

Anzai-Kanto et al, (2005) compared the quality and quantity of DNA extracted from saliva directly collected from the mouth to that deposited by a swab over the skin. They found that DNA from saliva deposited on the skin by a swab was lower than that extracted from saliva directly. PCR was used to replicate thousands of copies of a DNA sequence in vitro and fifteen STRs of human genomic DNA were amplified. It was possible to match the alleles of these loci in all the tested saliva samples collected directly from the mouth and in only $90 \%$ of those deposited by a swab. This can be explained as; saliva deposition, salivary cell collection and DNA extraction procedures probably reduce the DNA quantity.

Quinque et al, (2006) studied the quality and quantity of DNA extracted from stored saliva, incubated in vials that contained a lysis buffer at $37^{\circ} \mathrm{C}$ for 30 days. They concluded that stored samples gave as mush DNA as fresh samples and amplification of different autosomal microsatellite loci by PCR provide accurate genotypes, even after storage.

Yudianto et al, (2011) related successful PCR amplification of DNA extracted from human saliva to appropriate DNA purity and quantity which can be strongly used for personnel identification.

Thirteen STR loci -used for paternity identification- were successfully amplified by PCR after DNA extraction from saliva and blood. The conditions for the PCR were optimized using the DNA from the saliva samples, and the same conditions were applied to the DNA extracted from blood yielding the same results, i.e., good quality and quantity of DNA extracted (Fraige et al., 2013).

Chávez-Briones et al, (2015) recorded the second case in forensic literature reporting the analysis of DNA isolated from bite marks present on a victim s' body in order to identify the perpetrator of a crime. Their results indicated that, despite of the small amount of saliva deposited on the skin during bites; in addition to environmental factors (heat, bacteria, moisture, and mold) which can render the DNA unusable. However, direct deposition of saliva on the skin, the use of a single swab technique for saliva collection and appropriate method of DNA isolation followed by PCR amplification; lead to good quality and sufficient quantity of DNA facilitating complete STR typing of the perpetrator in this case.

Cigarette butts are a common trace sample at crime scenes and obtaining DNA profiles from this evidence is important. However, the purity of DNA extracts from saliva deposited over cigarette butts were lower than the optimal range and cigarette butt samples are notably difficult to analysis as they contain DNA that are contaminated with PCR inhibitors such as phenolic, tars from the flavor additives, paper additives as well as the smoke also it may contain DNA that are degraded (Shepherd et al., 2012).

On the other hand, (Thirunavakarasua et al., 2016) presented the first study in Malaysia that exposed cigarette butts to outdoor and indoor conditions; they collected cigarette butts from volunteers then exposed them to outdoors (open field) and indoors (in the laboratory) for one, three and seven days prior to DNA extraction. The findings showed that the purity and concentration of DNA recovered from the saliva traces on cigarette butts exposed outdoors and over a longer period of exposure are lower than that exposed indoors and over a shorter period of exposure. Despite of that submitted cigarette butt samples to STR typing revealed full profiles in indoor samples and partial profiles for outdoors ones. This proved the possibility of identifying the perpetrator using DNA evidence recovered from cigarette butt samples.

The sensitivity of PCR can act as a double bladed weapon. On one hand the starting material can be used even if it was very small amount, old or degraded. But, on the other hand, very small amount of contaminating DNA (three categories of exogenous DNA have the biggest impact on DNA-typing: DNA from the analyst, from other samples in the lab or allelic ladder fragments) can also be amplified along with the sought DNA compromising the analysis of the genetic profile and consequently making identification of the individual impossible (Cavanaugh and Bathrick, 2018).

In the present study DNA from non-human sources, such as bacteria and fungi, hadn't been amplified nor detected as the chosen STR primers are humanspecific. Furthermore the choice of positive and negative 
controls confirms that every step has been set up correctly and helps in detection of contaminants. The positive control group was used to test the validity of (RSID $^{\mathrm{TM}}$-Saliva kit), the efficacy of DNA extraction method then to test the master mix, $\mathrm{MgCl} 2$ amounts, primer annealing temperature, and extension times as well as to check that the primer set works and that the reaction was set up properly. Furthermore, the negative control group that contains all essential components for saliva extraction, DNA extraction and amplification reaction except the template didn't give any bands when analyzed by agarose gel; this eliminate the occurrence of any contamination throughout the research work .

In the current study another issue which would hinder DNA amplification was the great possibility of DNA degradation; this was overcome by using appropriate extraction method as well as choosing three autosomal STR primers with relatively small size (ranging from 214 to $323 \mathrm{bp}$ ) which ends finally by successful amplification of the desired STR.

A successful PCR reaction requires a number of vital primary components; oligonucleotide primers which are complementary to the DNA target and mark the target to be amplified, with two primers being used. The base sequence of one primer binds to one side of the target whilst the other primer binds to the other side of the target, with the DNA between the primers being amplified. Fluorescent tags are often added to the primers to visualize amplified DNA in electrophoresis. The smaller size of STR alleles makes STR markers better candidates for use in forensic applications, in which degraded DNA is common. STR alleles also have lower mutation rates, which makes the data more stable and predictable. Because of these characteristics, STRs are chosen for human identification in forensic cases on a regular basis (Cavanaugh and Bathrick, 2018).

Another point to discuss about the results is the method employed to show the amplification. An agarose gel was used as it is low-coast, easy procedure and it is the standard method for analyzing reaction quality and yield of PCR products. Electrophoresis reveals the size of the product band, which was compared with the predicted result. Electrophoresis also shows how much of this band was produced, and reveals the presence or absence of any unintended amplification products. Ideally, electrophoresis yields a single strong band of correct size, that can be determined by comparison to a DNA ladder (a collection of DNA fragments of known lengths) running on the same gel. When a gel is stained with a DNA-binding dye and placed under UV light, the DNA fragments (bands) will glow, allowing seeing the DNA present at different locations along the length of the gel (Ambers et al., 2018).

\section{Conclusions and recommendations}

In conclusion, the current study demonstrated that saliva presents an ideal source for DNA. Samples can be stored for a relatively long duration at ambient temperatures before DNA extraction, with minimal loss of DNA quality; and it finally, yields a sufficient amount of DNA for a wide variety of applications. The study also evidenced that the new RSID $^{\mathrm{TM}}$-saliva kit is a reliable method for saliva identification over different surfaces. It also resists to environmental factors up to 30 days. In addition, its detection protocol can be completely integrated into the standard protocols used for DNA extraction; followed by successful PCR amplification and agarose gel analysis proving that the genotypes obtained from saliva DNA are clear and accurate that makes saliva DNA valid for forensic identification. For the previous considerations it is recommended to widely use saliva as a source of DNA database for the general population. Draw the attention of forensic doctors and forensic researchers to saliva as an important evidence for personal identification that can be found in different crime scenes and which can solve many crimes and identify their perpetrator (e.g. sexual assaults, paternity, etc....).Usage of $\mathrm{RSID}^{\mathrm{TM}}$ Kits is highly recommended for body fluids identification (saliva, blood, semen, vaginal, urine, etc...) as it is sensitive, specific, easy, resists environmental conditions and presumptive test to DNA extraction. Further studies should be carried out to find more body sources for DNA as well as more specific methods for human identification. It is also recommended to quantify and analyze the condition of DNA extracted from saliva using the commonly used methods for qualification, and to perform a full DNA typing profile using the 15 STRs recommended by the FBI in forensic cases.

\section{References}

Ambers A, Wiley R, Novroski N, et al., (2018):Direct PCR amplification of DNA from human bloodstains, saliva, and touch samples collected with microFLOQ ${ }^{R}$ Swabs. Forensic Science International: Genetics. 32: 80-87.

Anzai-Kanto E, Hirata MH, Hirata RDC et al., (2005):

DNA extraction from human saliva deposited on skin and its use in forensic identification procedures. Braz. Oral. res. 19(3): 216-222.

Beltzer EK, Fortunato CK, Guaderrama MM et al., (2010):Salivary flow and alpha-amylase: Collection technique, duration, and oral fluid type. Physiol. Behav. 101(2): 289-96.

Biosearch Technologies (LGC): https://www.biosearchtech.com/products.

Carvalho SPM, Sales-Peres A, Ribeiro-Bicudo LA et al., (2010).Quality evaluation of DNA obtained from stored human saliva and its applicability to identification in Forensic Dentistry. Rev. Odonto. Ciênc. 25(1): 48-53.

Casey DG and Price J (2010):The sensitivity and specificity of the RSID-saliva kit for the detection of human salivary amylase in the forensic science laboratory, Dublin, Ireland. Forensic Sci. Int. 194: 67-71.

Cavanaugh SE and Bathrick AS (2018):Direct PCR amplification of forensic touch and other 
challenging DNA samples: A review: Forensic science international: Genetics. (32): 40-49.

Chávez-Briones ML, Hernández-Cortés R, JaramilloRangel G. and Ortega-Martínez M (2015):Relevance of sampling and DNA extraction techniques for the analysis of salivary evidence from bite marks: a case report. Genetics and Molecular Research. 14 (3): 10165-10171.

Fraige K, Travensolo RF, and Carrilho E (2013):Analysis of seven STR human loci for paternity testing by microchip electrophoresis. Braz. Arch. Biol. Technol. 56(2): 213-221.

Goode MR, Cheong SY, Li N et al., (2014):Collection and extraction of saliva DNA for next generation sequencing. J. Vis. Exp. 90(51697e): 1-7.

Holtkötter H, Schwender K, Wiegand $\mathrm{P}$ et al., (2018):Improving body fluid identification in forensic trace evidence-construction of an immunochromatographic test array to rapidly detect up to five body fluids simultaneously. Int. J. Legal Med. 132: 83-90.

Independent Forensics (2016):Rapid Stain Identification of Human Saliva (RSID ${ }^{\text {TM}}-$ Saliva), Technical Information \& Protocol Sheet for Use with Universal Buffer, Reduced Incubation Time Cat\# 0130. http://www.ifi-test.com/documents/022416short-incub-SALIVA-Universal-Buffer1.pdf (Last assessed 15 May 2018).

McAllister P, Graham E, Deacon P et al., (2016):The effect of mark enhancement techniques on the subsequent detection of saliva.Science and Justice. 56: 305320.

Nanda KD , Ranganathan K, Umadevi KM and Joshua E (2011):A rapid and non-invasive method to detect dried saliva stains from human skin using fluorescent spectroscopy. J. Oral. Maxillofac. Pathol. 15(1): 22-25.

Old JB, Schweers B, Boonlayangoor PW et al., (2010):Developmental Validation of RSID $^{\mathrm{TM}}$ Saliva: A Lateral Flow Immunochromatographic Strip Test for the Forensic Detection of Saliva. J. Forensic Sci. 54(4): 866-873.

Pang BCM and Cheung BKK (2008):Applicability of two commercially available kits for forensic identification of saliva stains. J. Forensic Sci. 53: 1117-1122.

Park HY, Son BN, Seo YI et al., (2015):Comparison of four saliva detection methods to identify expectorated blood spatter. J. Forensic Sci. 60(6):1571-1576.

Protocol of HotStarTaq ${ }^{\circledR}$ PCR Handbook (2010):HotStarTaq DNA Polymerase, HotStarTaq Master Mix Kit For highly specific hot-start PCR without optimization. October 2010. Page 1-44. https://www.qiagen.com/us/resources/download.as px?id=53e71936-cf64-4a9b. (Last assessed 26 April 2018).

Qiagen extraction kit QIAamp® DNA Mini and Blood Mini Handbook (2016):For DNA purification from whole blood, plasma, serum, buffy coat, lymphocytes, dried blood spots (QIAamp DNA Mini Kit only), body fluids, cultured cells, swabs, and tissue (QIAamp DNA Mini Kit only). ( $\left.5^{\text {th }} \mathrm{Ed}\right)$. Page:

$1-72$. https://www.qiagen.com/ch/resources/download.as px?id=62a200d6-faf4-469b. (Last assessed 26 April 2018).

Quinque D, Kittler R, Kayser M et al., (2006) : Evaluation of saliva as a source of human DNA for population and association studies. Anal. Biochem. 353(2006): 272-277

Ricci U, Carboni I, and Torricelli F (2014):False-positive results with amylase testing of citrus fruits. $\mathrm{J}$. Forensic Sci. 59(5): 1410-1412.

Saukko P and Knight B (2016): Pathophysiology of death. In: Forensic pathology, $\left(4^{\text {th }} \mathrm{Ed}\right), \mathrm{CRC}$ press Taylor and Francis group, Boca Raton, Florida. Ch 2 Page: 54-95.

Shepherd C, Harbison S and Saul DJ (2012): Extraction of DNA from cigarette butts using forensicGEM® Cigarette. ZyGEM Application Note 102. New Zealand: ZyGEM Corporation Ltd. http://www.tataa.com/wpcontent/uploads/2012/10/forensicGEMCigarette-AppNote_DNAextraction.pdf (Last assessed 16 May 2018).

Sinelnikov A, Kalinina A, Old JB et al., (2013):Evaluation of rapid stain identification $\left(\mathrm{RSID}^{\mathrm{TM}}\right)$ reader system for analysis and documentation of RISD ${ }^{\text {TM }}$ tests. Appl. Sci. 3(3): 624-635.

http://www.ifi-test.com/wpcontent/uploads/2016/10/022416\%20short\%20in cub\%20SALIVA-Universal\%20Buffer.pdf (Last assessed 26 April 2018).

Thirunavakarasua T, Ahmada UK, Khanb $\mathrm{HO}$ and Rahmatc Z (2016):DNA Analysis of Saliva Traces on Cigarette Butts Exposed to Indoor and Outdoor Environmental Conditions. Malaysian Journal of Forensic Sciences, 7(1):10-16.

Trepat EV and Castelló A (2015): More about RSID ${ }^{\mathrm{TM}}$ saliva: the effect of sample age and the environment on the test's efficacy. Aust. J. Forensic Sci. 47(4): 450-455.

Virkler K and Lednev IK (2009): Analysis of body fluids for forensic purposes: From laboratory testing to non-destructive rapid confirmatory identification at a crime scene. Forensic Science International. 188: $1-17$

Yudianto A, Lindawati $\mathrm{T}$ and Hanindito $\mathrm{P}$ (2011):Effectiveness of nuclear DNA mini primer set at loci FGA, CSF1PO and D21s11 in high-Temperature DNA degradation with polymerase Chain reaction (PCR) Method. Folia. Medica. Indonisiana. 47(3):154-159. 


\section{الملخص العربي}

\section{علامة حيوية صبغية سريعة: وسيلة جديدة للكشف الطى الشرعى عن اللعاب (تأثير الوقت و السطح على موثوقيته)}

\section{نسرين عبد الرحمن محمود' و على محمد ذكى}

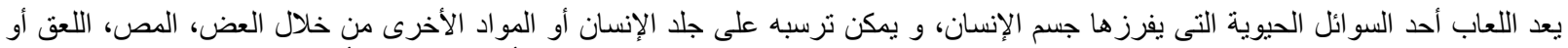

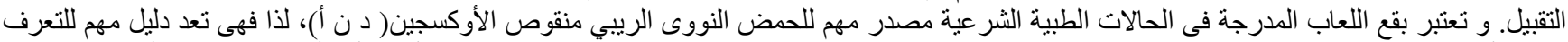

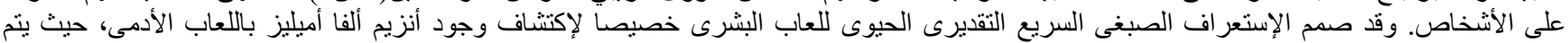

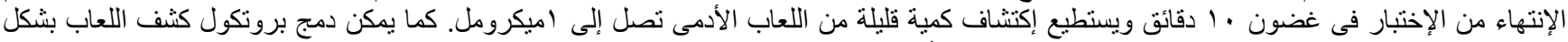

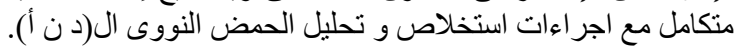

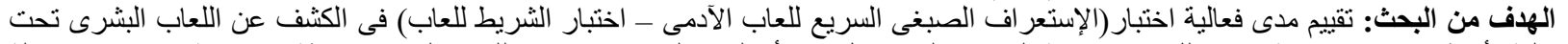
متغير ات مختلفة (أسطح وفترات زمنية )، وكذلك تقييم نو عية الحمض النووى ال(د ن أ) المستخلص من عينات اللعاب الغير محفوظة و إدكانية استخدامها كدلالة اللئل

"طريةة البحث: نم جمع اثتنا وخمسين عينة لعاب من أربعة متطو عين، حيث تم وضع ثمانى و أربعين منهم على أسطح مختلفة (حاويات بلاستيكية ،

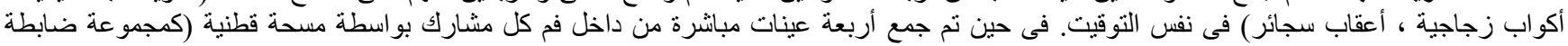

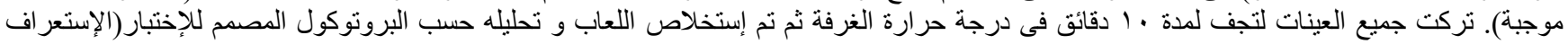

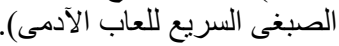

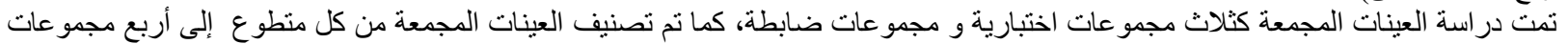

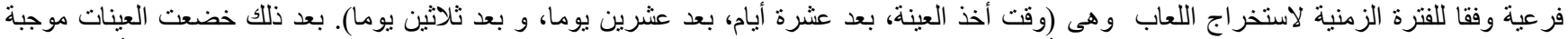

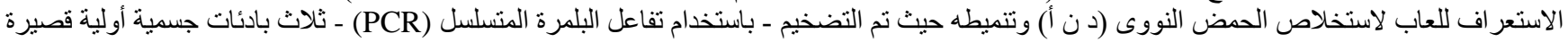

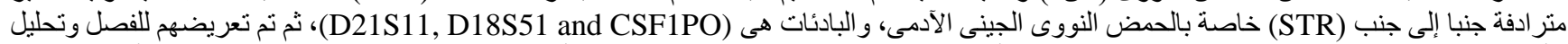

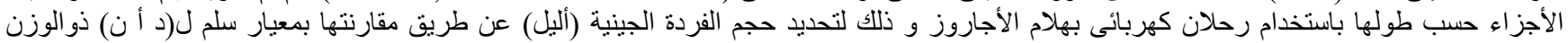

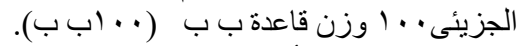

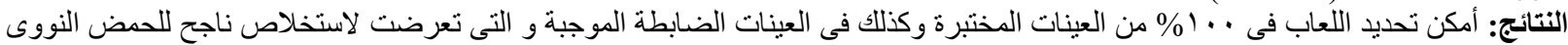

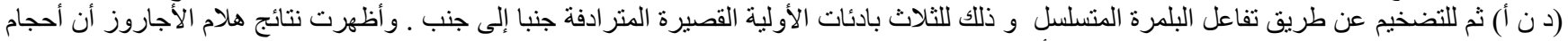

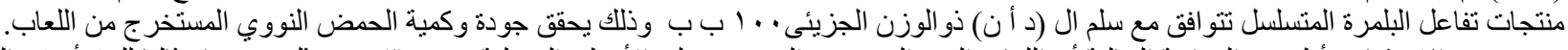

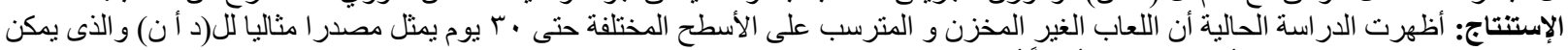

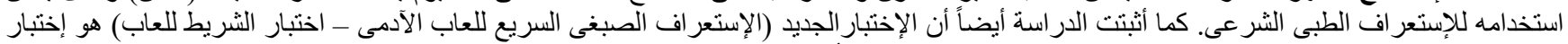
سريع ، بسيط ، حساس ووسيلة يعتمد عليها للإستعر اف على اللعاب على الأسطح المختلفة. 